\title{
OBLIKE KOLEKTIVNEGA SPOMINJANJA NA GENERALA MAISTRA
}

Povzetek V članku so analizirane javne oblike dediščenja spomina na generala Rudolfa Maistra na Ministrstvu za obrambo in v Slovenski vojski. Raziskano je, kako se v ikonografiji javno izpostavljenih umetniških del v fizični obliki, poimenovanjih objektov in priznanj ter slovesnih ritualnih praksah odslikava Maistrova vojaška kariera. Na podlagi ovrednotenja najpogostejših javnih oblik spominjanja je narejen sklep, koliko je to stvarno kolektivno spominjanje, ki želi ohranjati ter spodbujati naklonjen odnos do slovenskega vojaškega strateškega vodja, zaslužnega, da je pomemben del slovenskega narodnostnega ozemlja del današnje Republike Slovenije.

Ključne General Rudolf Maister, vojaški strateški vodja, slovenska vojaška zgodovina, besede junaštvo, javne predstavitve.

Abstract The article provides an analysis of the public forms of inheriting the memory of General Rudolf Maister at the Ministry of Defence of the Republic of Slovenia and in the Slovenian Armed Forces. It investigates how Maister's military career is reflected in the iconography of publicly exposed works of art in a physical form, the naming of objects and recognitions, as well as in ceremonial rituals. Based on the evaluation of the most common forms of public remembrance, it provides a conclusion as to how tangible this collective remembrance actually is, which seeks to maintain and promote a favourable attitude towards this Slovenian military strategic leader owing to whom an important part of Slovenian national territory today forms a part of the Republic of Slovenia

Key words General Rudolf Maister, military strategic leader, Slovenian military history, heroism, public representations. 
Uvod General Rudolf Maister je edina vojaška osebnost, po kateri je poimenovan slovenski državni praznik ${ }^{1}$. Dan Rudolfa Maistra kot državni praznik v Sloveniji praznujemo od leta 2005, in sicer 23. novembra - v spomin na 23. november 1918, ko je Maister prevzel vojaško oblast v Mariboru. Državni praznik, poimenovan po generalu, je pomemben pokazatelj vrednosti za narod, ki mu jo slovenska družba priznava, saj državni prazniki odslikavajo, kaj je v neki državni skupnosti vrednostno in politično pomembno; ne nazadnje se je koledar državnih praznikov na Slovenskem skozi daljše obdobje in spremembe družbenih sistemov precej spreminjal. Kot utemeljuje Slavec Gradišnik, »koledarji v družbeni red in prakse skupnosti, ki so jim namenjeni, s ponavljanjem zapisujejo vrednote >skupnega<, materializirane na primer na spominjanje na mite o izviru skupnosti, odločilne dogodke in osebnosti« (2017, str. 10). Taškar Maistra v novinarskem članku o uvedbi treh novih praznikov leta 2005 navaja, da je bil Maister uporabljen kot »konstitutivni element državne teritorialne celovitosti« (2005, str. 2).

Ob osredinjenju na vprašanje, zakaj je general Rudolf Maister pomemben za slovenski obrambni sistem, se opiramo na trditev kulturnega antropologa Simoniča, da je bil general Rudolf Maister »prvi general v slovenski zgodovini, ki je pomembno vplival na oblikovanje slovenske države« (2021, str. 267). Gre torej za Slovenca z izjemno častniško kariero, ki je dokazal in opozoril na državotvoren pomen svojega poklica oziroma poslanstva. Kot ugotavlja Furlan, je »spoznal kritičnost trenutka za doseganje strateških nacionalnih ciljev - trenutka za akcijo, odgovor na razvijajočo se situacijo; akcijo, ki jo lahko izpelje samo vojaška organizacija« (2013, str. 79). Predpostavljamo, da gre pri dojemanju generala Maistra kot vzornika v obrambnem sistemu za velik pomen dejstva, da je vojaška osebnost s celovitim pristopom (kot častnik in kot pogajalec s civilno oblastjo) izpeljala daljnosežen državotvoren projekt obranitve narodnostnega ozemlja v mejah novonastale države jugoslovanskih narodov in tudi $\mathrm{v}$ mejah prihodnje slovenske nacionalne države ter tako uresničila eno izmed poglavitnih ambicij naroda, ki je bil do takrat podrejen nemški strani.

Življenjska zgodba generala Maistra in njegovih zaslug za narod vsebuje tudi veliko spektakularnost, katere zelo očitna elementa sta gotovo drznost ob prevzemanju veliko večje odgovornosti od trenutne dolžnosti, samoiniciativno predlaganje napredovanja iz majorja $\mathrm{v}$ generala ter vizionarski izkoristek pravega zgodovinskega trenutka. O tem govori tudi Guštin: »Maister je svoj načrt dosledno izvajal, kljub temu, da so bili njegovi vojaški in civilni predpostavljeni drugače misleči. Prepričan je bil, da deluje v nacionalnem interesu. Imel je dovoljšnjo svobodo ukrepanja, ker je bila vojaška poveljevalna veriga še ohlapna in nedorečena. Njegovo vojaško razmišljanje in ukrepanje se je izkazalo za bolj učinkovito kot zaupanje v mirno

\footnotetext{
V Republiki Sloveniji se praznujeta še dva državna praznika, neposredno povezana z osebnostmi, zaslužnimi za narod, in sicer sta to slovenski kulturni praznik Prě̌ernov dan in dan Primoža Trubarja. Generala Maistra ob Franceta Prešerna in Primoža Trubarja postavlja v posebnem pogledu tudi Partljič z izjavo: »Slovenci, ki smo doslej vse svoje mite le razbijali, imamo možnost, da poleg Trubarja ali Prě̌erna mitiziramo tudi Rudolfa Maistra« (2011, str. 28).
} 
rešitev« (2011, str. 34). Menimo, da tudi ta spektakularnost vsebuje veliko možnosti za ustvarjanje javnih oblik spominjanja na generala Rudolfa Maistra.

Ugotavljamo, da bi lahko generala Maistra na podlagi taksonomije heroizma, ki jo je naredil Zimbardo, uvrstili v podskupino političnih ali vojaških voditeljev. ${ }^{2}$ Slednji navaja, da je za to podskupino junakov značilno, da vodijo narod ali skupino skozi težavno obdobje; pripomorejo k temu, da bi združili narod; so avtorji skupne vizije ter utelešajo lastnosti, ki so nujne za narodovo preživetje. Med njimi avtor navaja Abrahama Lincolna, Roberta E. Leeja, Franklina Roosevelta, Winstona Churchilla in Vaclava Havla. Kot grožnje, ki junakom te podskupine grozijo, pa omenja »atentat, razrešitev s funkcije, upor, načrtovane kampanje z namenom očrnitve in zaporno kazen« $\left(2007\right.$, str. 468-471). ${ }^{34}$

Obdobje stotih let, ki je minilo od zgodovinskega dejanja generala Maistra, je čas, po katerem ni več živih borcev, ki so se z njim bojevali, prav tako je verjetno živih še zelo malo ljudi, ki so ga osebno poznali. Družbene spremembe v tem obdobju so bile velike. Predvidevamo, da gre za časovno distanco, v kateri se lahko pogled na zaslužnega posameznika v širši skupnosti že izoblikuje in utrdi.

Namen prispevka je preučiti najpogostejše javne oblike spominjanja na generala Maistra znotraj Ministrstva za obrambo in Slovenske vojske ter na podlagi tega ugotoviti, katera dejstva iz njegovega življenja in delovanja ter katere značilnosti njegove vizualne podobe so v teh oblikah najizraziteje vsebovane. Zanima nas, ali te oblike spominjanja prikazujejo lik generala Maistra v celovitosti njegovega vojaškega in državniškega delovanja. Odgovoriti želimo tudi na vprašanje, ali gre pri teh oblikah za stvarno spominjanje nanj na podlagi objektivnega védenja zaradi ohranjanja ter spodbujanja naklonjenega odnosa do tega znamenitega slovenskega vojaškega strateškega vodja, ali pa ima občudovanje njegove osebnosti morda že očitne značilnosti odnosa do absolutnega, mitiziranega junaka.

\footnotetext{
Druge podskupine junakov, kot jih utemeljuje Zimbardo, so: vojaški in drugi junaki po dolžnosti z življenjskim tveganjem; civilni junaki, ki tvegajo svoje življenje; religiozne osebnosti; politično-religiozne osebnosti; mučeniki; pustolovci in odkritelji novih dežel; znanstveni izumitelji; človekoljubi; ljudje, ki premagajo svoj hendikep ali težavne okoliščine in postanejo zgled za druge; korporacijski junaki in »žvižgači« (2007, str. 468471).

3 Poskus klasifikacije generala Rudolfa Maistra kot junaka je objavljen že v Pavšič, 2019, str. 47-48.

4 To ugotovitev potrjuje dejstvo, da so generalu Maistru v resnici grozili z atentatom. Pismo z grožnjo, da bo nanj izveden atentat, je namreč 23. maja 1921 na uredništvo lista Ponedeljek iz Gradca odposlal nekdanji častnik pri avstroogrskem 97. pehotnem polku (Tržaškem polku) Cheron. Urednik lista Milan Plut je posredoval pismo 12. junija 1921 Deželni vladi za Slovenijo. Iz Poverjeništva za notranje zadeve so 20. junija 1921 pisali policijskemu ravnateljstvu v Ljubljani, policijskemu komisariatu v Mariboru, komisariatom železniške in obmejne policije na Rakeku, v Mariboru in na Jesenicah, generalu Maistru in konzularnemu predstavništvu Kraljevine SHS v Gradcu. Na srečo se je pokazalo, da je grožnja neutemeljena (Arhiv Republike Slovenije 1).
} 


\section{PREDPOSTAVKE VREDNOTENJA POMENA GENERALA MAISTRA NA MINISTRSTVU ZA OBRAMBO IN V SLOVENSKI VOJSKI}

$\mathrm{Ob}$ začetku raziskave smo si zastavili vprašanje, ali izkazana tradicija in način dediščenja spomina na generala Maistra v resnici kažeta na to, da je general Rudolf Maister vzornik pripadniku Slovenske vojske. Na tej podlagi lahko v nadaljevanju utemeljujemo, da gre pri dediščenju spomina na generala Maistra za tri razsežnosti, ki ga v vrednostnem sistemu slovenskega obrambnega sistema določajo za izjemnega. Te so: dosežen čin generala, njegovo vojaško delovanje pred prevratom in po njem (v bojih za slovensko severno mejo) ter vpliv na oblikovanje slovenske države in njeno ozemeljsko celovitost $t^{5}-\mathrm{z}$ zadnjim je tudi obrambna oziroma vojaška dejavnost razumljena kot zelo pomembna za doseganje državotvornih interesov. Menimo, da mu te tri razsežnosti dajejo status junaka, kar se kaže tudi v javnih oblikah spominjanja.

\subsection{Vojaška kariera Rudolfa Maistra pred prevratom}

Kot piše Maistrov biograf Hartman, je Rudolf Maister (rojen 29. marca 1874 v Kamniku) šesti razred ljubljanske gimnazije uspešno opravil leta 1892, a jo je zapustil in nadaljeval šolanje v domobranski kadetnici (Landwehrkadettenschule) na Dunaju. ${ }^{6}$ Tam se je šolal od svojega 18. do 20. leta starosti ${ }^{7}(1998$, str. 15).

Mladi kadet oziroma častniški namestnik je s činom praporščaka, ki ga je dobil 18 . avgusta 1894, nadaljeval svojo vojaško kariero v domobranskem polku v Ljubljani, naslednje leto pa v domobranskem polku v Celovcu. 1. novembra 1895 je bil povišan v čin poročnika (Vojni arhiv Ministarstva odbrane Republike Srbije). Tega leta je bil spet premeščen v Ljubljano, kjer je opravljal različne naloge. ${ }^{8} \mathrm{~V}$ več kot desetih letih službovanja v Ljubljani je na številnih vajah dobro spoznal slovensko ozemlje. Vmes se je tudi izpopolnjeval, in sicer od 1. novembra 1896 do aprila 1897 v jezdarski (jahalni) šoli za pehotne oficirje v Ljubljani in leta 1903 ali 1904 pet tednov v armadni strelski šoli v Brucku na Leithi. ${ }^{9} \mathrm{~V}$ čin nadporočnika je bil povišan 1. maja 1900 (Vojni arhiv Ministarstva odbrane Republike Srbije). Ker je veljal za sposobnega, nadarjenega, bistrega, željnega pridobivanja novih znanj in trdnega značaja, so ga poslali na polletni študij od 1. decembra 1896 do konca maja 1907

\footnotetext{
Izraz uporabila Taškar (Delo, 2005, 2).

- Domobranska kadetnica je bila edina vojaška ustanova, ki je vzgajala bodoče častnike za to avstrijsko vojaško formacijo (domobranstvo, deželna obramba ali Landwehr).

Oborožene sile Avstro-Ogrske so bile sestavljene iz vojske (Heer), mornarice (Marine), deželne obrambedomobranstva (Landwehr) in črne vojske (Landsturm). Domobranstvo (kot druga bojna črta) je pomagalo vojski in skrbelo za obrambo v notranjosti države, izjemoma tudi za red in varnost v državi (Hartman, 1998, str. 15-16 in Glavan, 2018, str. 15).

7 Rudolf Maister je začel šolanje v domobranski kadetnici 17. avgusta 1892, končal pa ga je 17. avgusta 1894 (2006, str. 16).

8 Med drugim je bil orožar v četi in bataljonu, častnik na mestnem poveljstvu, uril je rezerviste.

${ }_{9}$ Z uspešnim šolanjem na armadni strelski šoli se je usposobil za orožarskega častnika. V literaturi se ves čas navaja, da je bil na šolanju na armadni strelski šoli leta 1903, v personalnem kartonu generala Rudolfa Maistra pa lahko preberemo zapis, da je bil leta 1904 (Vojni arhiv Ministarstva odbrane Republike Srbije).
} 
na častniško šolo 3. armadnega zbora v Gradcu. Uspešen zaključek tega šolanja je bil pogoj za povišanje v čin stotnika, kar se je uresničilo 1. maja 1910 (Vojni arhiv Ministarstva odbrane Republike Srbije). Danes smo prepričani, da mu je ob koncu prve svetovne vojne neposredno spoznavanje terenov na Štajerskem in Koroškem zelo koristilo v zgodovinsko pomembnem trenutku vzpostavljanja novih državnih mej po prvi svetovni vojni.

Nadporočnik Rudolf Maister je bil novembra leta 1908 kazensko ${ }^{10}$ premeščen k domobranskemu polku št. 18 v Przemyśl v Galiciji, ${ }^{11}$ kjer je leta 1912 postal poveljnik podčastniške šole, na vojaških vajah pa je zelo hudo zbolel ${ }^{12}$ (Vojni arhiv Ministarstva odbrane Republike Srbije).

Po dopustu je bil premeščen iz domobranstva v črno vojsko (Landsturm) ${ }^{13}$. Tako je 1. novembra 1913 postal poveljnik črnovojniške izpostave v Celju, 7. decembra 1914 pa referent pri črnovojniškem okrožnem poveljstvu št. 26 v Mariboru. 21. junija 1916 so ga postavili za začasnega poveljnika okrožnega črnovojniškega poveljstva št. 26 v Mariboru, a je bil zaradi svojega odkritega podpiranja in delovanja za slovenstvo ter številnih pritožb nemško zavednega prebivalstva v Mariboru 8. marca 1917 premeščen v Gradec k črnovojniškemu okrožnemu poveljstvu št. 3 (Potočnik, 2008, str. 56). Med službovanjem v Gradcu so ga 1. maja 1917 povišali v čin majorja (Vojni arhiv Ministarstva odbrane Republike Srbije). Njegova visoka in izkazovana slovenska narodna zavednost je bila razlog za številne službene težave in disciplinske kazni. ${ }^{14}$ Po štirimesečni odsotnosti se je major Rudolf Maister spet vrnil v Maribor. ${ }^{15}$

\subsection{Okoliščine ob povišanju majorja Rudolfa Maistra v generala s strani Narodnega sveta za Štajersko in njegov status generala}

Pravnik in zgodovinar, nekdanji prostovoljec v boju za severno mejo Lojze Ude je zapisal, da je bil čas po koncu prve svetovne vojne tisti zgodovinski trenutek, ko je bilo treba hitro ukrepati za zavarovanje slovenskih narodnostnih mej (Arhiv Republike Slovenije 2). Narodna vlada Slovencev, Hrvatov in Srbov (SHS) v Ljubljani pa je bila glede severne slovenske meje naivno prepričana, da bo začrtana tako, kot bo to kot »antantna zaveznica« v družbi s Srbijo zahtevala (Arhiv Republike Slovenije 2).

\footnotetext{
${ }^{10}$ Kot piše Glavan, naj bi bil vzrok za kazensko odločitev Maistrova narodna ozaveščenost (2018, str. 23).

${ }^{1 I}$ Kot še navaja Glavan, je prvih osem mesecev general Maister v Galiciji bival sam. Nato se je za njim preselila tudi njegova družina, vključno z materjo. (prav tam)

${ }_{12}$ Na zdravniškem pregledu so ugotovili, da je hud pljučni bolnik, zaradi vnetja rebrne mrene je bil devet mesecev na bolniškem dopustu. Tudi tukaj se srečamo z neskladjem podatkov med podatkom v personalni oziroma kadrovski mapi, v kateri je zapisano, da je bil na bolniškem dopustu devet mesecev, in v literaturi, ki navaja, da je bil šest mesecev na bolniškem dopustu (Hartman, 1998, str. 21, in Potočnik, 2008, str. 56).

13 Črna vojska (Landsturm) je v oboroženih silah Avstro-Ogrske kot tretja črta (zaledno) podpirala vojsko, mornarico in domobranstvo (Hartman, 1998, str. 15-16).

${ }_{14}$ Povzeto po: Koblar. Slovenska biografija. Maister, Rudolf. https://www.slovenska-biografija.si/oseba/sbi340526/. 30. 4. 2021.

${ }_{15}$ Rudolf Maister je bil v konfinaciji v Gradcu od dva do tri mesece. Za vrnitev v Maribor se je moral zahvaliti dr. Antonu Korošcu, ki je bil takrat predsednik Jugoslovanskega parlamentarnega kluba (Vojni arhiv Ministarstva odbrane Republike Srbije).
} 
Ker Država SHS formalno mednarodnopravno ni bila priznana, Slovenci po vojni niso mogli nastopati kot »antantni zaveznik«. Vse, kar so storile zavezniške vlade, je bilo, da so »vzele na znanje državnopravno spremembo, ki je na jugu Avstro-Ogrske nastala 29. oktobra 1918« (Perovšek, 2006, str. 186).

Zadržanost Narodne vlade Slovencev, Hrvatov in Srbov v Ljubljani postane razumljiva ob upoštevanju splošne stiske slovenskega naroda ob koncu vojne in razpadu Avstro-Ogrske monarhije. Italija je na podlagi Londonskega sporazuma z dne 26. aprila 1915 začela zasedati slovenska ozemlja, čemur Država SHS ni mogla odkrito nasprotovati, saj je od antante pričakovala mednarodno priznanje, prek slovenskega ozemlja pa so se vračale na svoje domove množice vojakov razpadle avstro-ogrske vojske; treba je bilo poskrbeti za red in mir. K začetni zadržanosti Narodne vlade SHS so prispevali tudi splošna vojna naveličanost ljudi in njihovo hrepenenje po miru, še posebej vojakov, ki so bili v petem letu vojne (Guštin, 2006).

Prvi, ki je dal znak, da je nujna hitra akcija, ne pa pasivno čakanje na sklepe mirovne konference, je bil major in poveljnik 26. črnovojniškega okrožja v Mariboru Rudolf Maister, v literaturi poimenovan kot prvi prostovoljec v bojih za slovensko severno mejo v letih 1918/19 (Arhiv Republike Slovenije 3).

Tudi že pred generalom Rudolfom Maistrom so v različnih vojskah delovali Slovenci, ki so dosegli čin generala oziroma admirala. ${ }^{16}$ Menimo, da je treba natančno zapisati, general katere vojske je bil Maister. Kot navaja Grdina, ga je »Narodni svet za Štajersko ${ }^{17}$ ob osvoboditvi Maribora 1. novembra 1918 imenoval za generala brez natančnejše opredelitve častniške oziroma generalske stopnje« (2018, str. 77). »Še preden pa je bil njegov >veliki dan< končan, torej še 1. novembra 1918, je Narodni svet Rudolfa Maistra povišal kar za tri stopnje in ga imenoval za generala nove vojske Države Slovencev, Hrvatov in Srbov. Za to gesto pa jih je moral spodbosti kar sam, da bi z ustreznim činom v skladu z vojaškimi normativi lahko uspešno nastopal pri nemških častnikih. Mesec in pol kasneje se je z imenovanjem sprijaznila tudi ljubljanska vlada.

\footnotetext{
${ }^{16}$ Omenimo le nekaj avstroogrskih: kontraadmiral cesarske in kraljeve mornarice Otto Balzar, veliki admiral Anton Haus, baron in generalmajor August Blaha pl. Zahenringen, baron in generalmajor Alfred Klement, generalmajor Ferdinand Kopriva, generalmajor Viktor Krainz (Krajnc), baron in feldmaršalporočnik Janez Lavrič pl. Zaplaz, baron in feldmaršalporočnik Emil Linhart, mornariški generalni komisar Rupert Pivec, generalmajor Emanuel Piwetz, častni kontraadmiral Rihard Pogatschnigg (Pogačnik), generalmajor Janez Pregelj, kontraadmiral Anton Račič, baron in generalmajor Friderik Širca (skladatelj Risto Savin), baron in feldmaršal poročnik Joža Tomše pl. Savskidol, baron in pehotni general Blaž Žemva, baron in pehotni general Janez Žemva (Kranjc, 2005).

17 26. septembra 1918 je bil v Narodnem domu v Mariboru ustanovljen Narodni svet za Štajersko, ki je bil pokrajinski odsek avgusta 1918 ustanovljenega Narodnega sveta za slovenske dežele in Istro v Ljubljani. Narodni svet za Štajersko je pod vodstvom predsednika dr. Karla Verstovška in podpredsednikov dr. Franja Rosine ter dr. Josipa Hohnjeca v trimesečnem času svojega delovanja (26. september-30. december 1918) utemeljil vsa najpomembnejša dejanja narodne osvoboditve na slovenskem Štajerskem. V oktobru 1918 je po mestih z nemško upravo ustanovil več krajevnih odborov in narodnih straž, 29. oktobra 1918, ob razpadu Avstro-Ogrske, pa je odpravil avstrijsko državno upravo in uvedel samostojno vlado Narodnega sveta. 1. novembra 1918 je Narodni svet za Štajersko prevzel tudi pošto in železnico, majorju Rudolfu Maistru pa podelil čin generala ter izročil vrhovno poveljstvo nad vsem vojaštvom, ki je bilo podrejeno svetu (Enciklopedija Slovenije, zv. 7 (1993), str. 319, glej tudi Perovšek, 1998 in 2018). Med drugim je prva slovenska Narodna vlada prvič uvedla slovenski jezik kot uradni jezik na območju Slovenije.
} 
Narodna vlada, v kateri je bil poverjenik za narodno obrambo dr. Lovro Pogačnik (1880-1919), je to imenovanje potrdila s 1. decembrom 1918. Potrditev so opravili zaradi izrednih zaslug in odločnega delovanja pri razglasitvi Jugoslavije na poseben način. Rudolfa Maistra je povišala z odlokom v čin polkovnika z naslovom in značajem generalmajorja« (Švajncer, 2014, str. 35, Glavan, 2018, str. 34).

Rudolf Maister je tako postal general vojske Države Slovencev, Hrvatov in Srbov, ki je nastala 29. oktobra 1918. Z združitvijo s Kraljevino Srbijo je 1. decembra 1918 nastala Kraljevina Srbov, Hrvatov in Slovencev in tako je tudi general Maister postal general vojske kraljevine. Uradno je bil general Rudolf Maister sprejet v skupno vojsko 28. novembra 1919 v činu generala ${ }^{18}$ (Vojni arhiv Ministarstva odbrane Republike Srbije). Sprejem v skupno vojsko je bil uradno objavljen v Vojaškem uradnem listu (Službeni vojni list, br. 48/1919, 3. december 1919, str. 1269).

V Vojski Kraljevine SHS/Jugoslavije je doseglo čin generala še 19 Slovencev, ${ }^{19}$ med njimi tudi sedem Maistrovih borcev. ${ }^{20}$

Če povzamemo, je Maistrova vojaška kariera dosegla vrhunec, ko je izvedel vizionarsko domoljubno akcijo, ki jo je skrbno načrtoval ves čas službovanja $\mathrm{v}$ Mariboru.

\subsection{Maistrove zasluge za ohranitev slovenskega narodnostnega ozemlja na Štajerskem v trajno slovensko posest}

30. oktobra 1918 je mariborski nemški občinski svet razglasil Maribor z okolico za del Nemške Avstrije. Že dan prej, 29. oktobra 1918, je bila na velikih manifestacijah v Ljubljani in Zagrebu razglašena Država Slovencev, Hrvatov in Srbov. Prvega novembra 1918 je major Rudolf Maister kot poveljnik mariborskega okrožja črne vojske v vojašnici 26. strelskega polka v Melju pred mestnim poveljnikom polkovnikom Antonom Holikom in zbranimi častniki izjavil: »Ne priznavam teh točk. Maribor razglašam za jugoslovansko posest in prevzemam v imenu svoje vlade vojaško poveljstvo nad mestom in vsem Spodnjim Štajerskim« (Pokrajinski arhiv Maribor 1).

Kot piše Švajncer, je Narodni svet prevzel upravo na slovenskem Štajerskem, general Rudolf Maister pa je postal komandant Vojaškega poveljstva za spodnji Śtajer $^{21}$ (2014, str. 43). Prvega novembra 1918 je Rudolf Maister prevzel vojaško

\footnotetext{
${ }^{8}$ V sklepu številka 124981 z dne 28. novembra 1919 je zapisano, da bo natančneje opredeljen generalski rang pozneje (Službeni vojni list, št. 48., 3. december 1919, str. 1269).

${ }^{19}$ Pogojno lahko zapišemo 20. Med generale vojske Kraljevine Jugoslavije, ki so bili slovenskega rodu, uvrščamo tudi divizijskega generala Milana Plesničarja, ki je bil sicer rojen 7. 6. 1882 v Kragujevcu in ni nikoli opravljal vojaške službe na slovenskem ozemlju (Bjelajac, 2004, str. 247).

20 Še dva Slovenca, polkovnika vojske Kraljevine Jugoslavije Egon Škrinjar in Fran Tomše sta opravljala vojaško službo na generalski dolžnosti, vendar zaradi nemškega napada na kraljevino aprila 1941 nista bila povišana $v$ generalski čin (Kranjc, 2005, str. 117).

${ }^{21}$ Tako se je imenovalo najprej, pred preimenovanjem $v$ Štajersko obmejno poveljstvo.
} 
oblast v Mariboru iz nemških rok, kar je bilo na podlagi tega, da se je Narodni svet za Štajersko dopoldne istega dne odzval na njegovo zahtevo po podelitvi poveljniškega položaja in generalskega čina, odločilno ne le za osvoboditev Maribora, temveč tudi za poznejše dogodke v mestu in na zunanjem področju njegovega poveljevanja (Maister, 1979). Tako si je Rudolf Maister pridobil tudi politično podporo (Guštin, 2006). Po tem uspehu je Maister zbrane vojake v meljski vojašnici seznanil, da je prevzel vrhovno vojaško poveljstvo v mestu in jih pozval, da vztrajajo v službi Jugoslavije (Maister, 1979). Po prvem navdušenju so slovenski vojaki obljubili, da ostanejo, a se jih je dopoldne kar nekaj, kot zapiše Maister, »izmuznilo iz vojašnice skupaj z nemškimi vojaki ..., dasi so dobro vedeli, v kako za nas skrajno nevarnem položaju se je nahajal Maribor s svojo neznatno slovensko posadko« (Maister, 1979, str. 17). V meljski vojašnici je tako ostalo sedem slovenskih častnikov in 87 slovenskih podčastnikov ter pešcev. Iz te skupine je general Maister sestavil 1. jugoslovansko stotnijo in za njenega poveljnika imenoval nadporočnika Jožeta Malenška (Maister, 1979). V topničarski vojašnici je nemški del moštva zapustil vojašnico, slovenski del pa je prostovoljno ostal pod poveljstvom podoficirja topničarja Joška Slobodnika. Bilo jih je približno 70 (Maister, 1979).

General Maister je za vojaško obvladovanje Maribora, zasedbo slovenske meje, njenih najpomembnejših točk in za razoroževanje vojaških transportov moral imeti disciplinirano vojaštvo, ki ga je bilo mogoče uporabiti tudi zunaj domačih občin. Pridobivanja prostovoljcev za omenjene naloge se je lotil tudi tako, da je na mariborskem glavnem kolodvoru ustavljal slovenske vojake, ki so se iz Avstrije vračali na svoje domove. Tako je v noči s 1 . novembra na 2. november zaustavil transport častnikov in visokošolcev, ki so bili iz Gradca namenjeni v Ljubljano. Častniki, ki jih je poznal še iz Gradca, so se njegovemu povabilu navdušeno odzvali. Tako je dobil pomoč 100 slovenskih vojakov 2. gorskega strelskega polka, ki je potoval iz Ennsa proti Ljubljani (Ude, 1961). Kljub začetnemu navdušenju vsi vojaki niso ostali in sledili čutu dolžnosti. ${ }^{22}$

9. novembra 1918 je general Maister razglasil mobilizacijo na območju Štajerskega obmejnega poveljstva ter v nekaj tednih zbral približno 4000 vojakov in 200 častnikov. ${ }^{23}$ 20. novembra 1918 je bil ustanovljen Mariborski pehotni polk s

\footnotetext{
${ }_{22}$ Šnuderl je v svoji, sicer literarno obarvani, kroniki o vojaških in političnih bojih v Mariboru in ob slovenski severni meji v letih 1918/19 glede ljubljanskega strelskega polka št. 2 iz Ennsa zapisal: „Drugi dan so Kranjci že prisegli. Tretji dan jih je dobršen del odkuril. Kar jih je pa ostalo, so bili trdni, hodili so s svojimi krivci za čepicami po mestu in se postavljali pred nemčurji« (Šnuderl, 1968, str. 159). Tisti prostovoljci, ki so ostali, so bili pripravljeni brezpogojno braniti slovenske meje in slediti ukazom generala Maistra. Jože Jelenc (18981998) iz Bukovščice v Selški dolini je bil do svoje smrti najstarejši Maistrov borec. V prvi svetovni vojni se je boril na soški fronti. Vojno je preživel in se vrnil domov, a le za kratek čas, kajti začeli so se boji za severno mejo. Z bratom Janezom sta bila med prvimi prostovoljci. Svojo udeležbo v bojih za severno mejo je utemeljil z naslednjimi besedami: "Zase nisem iskal pravice, bolela pa me je krivica, ki so jo živeli Slovenci izven naših meja. Prostovoljno sem šel v boj za te ljudi in ukradeno slovensko zemljo« (Križnar, 1998, str. 267, 271.)

${ }_{23}$ Poverjeništvo za narodno obrambo je dan prej, 8. novembra 1918, pozvalo vse obveznike od 18. do 40. leta starosti, da se odzovejo svoji patriotski dolžnosti. Poleg Ljubljane, Maribora in Celja je bil predviden tudi boroveljski kader (ARS 2). Kot je zapisal Ude, tukaj ni šlo za mobilizacijo, ampak za poziv na dolžnost do domovine. Naredba poverjeništva za narodno obrambo z dne 8. novembra ni bila mobilizacija, temveč le poziv na dolžnost (Ude, 1977, str. 139). Odziv je bil slab (Ude, 1977).
} 
slovenskimi častniki in slovenskim poveljevalnim jezikom. Eden najpomembnejših dogodkov se je zgodil 23. novembra 1918, ko je general Maister z odločnim poveljevanjem in delovanjem slovenskega vojaštva razorožil in pregnal iz mesta ter njegove okolice nemško varnostno stražo oziroma belo-zeleno gardo (Schutzwehr). Maribor je v celoti prešel pod njegovo poveljstvo. Tokrat je za izvedbo razoroževanja in zatrtja delovanja sovražnih enot zahteval od Narodne vlade SHS predhodno dovoljenje, a je dobil nejasen odgovor (Arhiv Republike Slovenije 3).

General Maister je odločilno vplival na to, da sta Maribor in Spodnja Štajerska ostala v slovenski posesti tudi v nadaljnjem določanju mej vse do današnjih dni, 23. november 1918 pa se je zapisal v slovensko državotvorno zgodovino. Od 25. novembra do 1. decembra 1918 je general Maister zasedel slovensko jezikovno mejo na črti Radgona-Špilje-Velikovec. Kot je sam zapisal, »je bil Maribor s to zasedbo trdno v naši oblasti« (1979, str. 63).

General Rudolf Maister je bil nadvse pozoren, da Slovenci ne bi zamudili izjemne zgodovinske priložnosti za uresničitev načrta, da se jim Maribor in preostalo slovensko etnično ozemlje na Štajerskem zagotovi v novi državi. Dejstvo je, da je Rudolf Maister pogumno in vizionarsko dejanje, s katerim je odločilno posegel v določitev meje na Spodnjem Štajerskem med novonastalima državama, naredil kot vojaška osebnost. Med dejanjem je s pomočjo lastnega poguma in premočrtnosti ter modre odločitve Narodnega sveta za Štajersko dosegel povišanje v generala, s čimer se je, kot piše Furlan, "povzpel s taktične na strateško raven poveljevanja« (2013, str. 73-74).

\subsection{Maistrovo vojaško delovanje v bojih za slovensko severno mejo}

General Maister je konec novembra 1918 dobil možnost, da kot poveljnik Štajerskega obmejnega poveljstva vpliva na reševanje koroškega mejnega vprašanja. Graško vojaško poveljstvo je poslalo polkovnika Rudolfa Passyja, da z Maistrom skleneta 27. novembra 1918 pogodbo o poteku razmejitvene črte. Pogodba je Slovencem dovoljevala zasedbo narodnega ozemlja na Štajerskem in Koroškem. Proti pogodbi so bili tako Nemci v Gradcu, Celovcu in na Dunaju kot tudi Narodna vlada v Ljubljani. Iz Gradca sta v Maribor prišla gospodarski komisar dr. Arnold Eisler in vojaški pooblaščenec Avgust Einspinner, ki sta generalu Maistru sporočila, da pogodba ni veljavna, da slovenske enote lahko zasedejo le Špilje, Lučane, Marenberg (Radlje ob Dravi) in Dravograd ter postavijo častniško stražo na radgonskem kolodvoru. Kljub Maistrovemu vztrajanju pri pogodbi so enote Mariborskega pehotnega polka zasedle večinoma kraje, ki sta jih navedla Eisler in Einspinner. ${ }^{24}$

\footnotetext{
${ }^{24}$ Konec novembra 1918 je general Maister odstavil nemške sodnike in upravitelje obeh pošt v Mariboru, kar je 29. novembra sprožilo stavko sodnih in poštnih uradnikov. Stavkati so začeli tudi železničarji, a jim je general Maister zagotovil varnost in vrnili so se na delo. Tudi stavka poštnih uradnikov in sodnikov je bila kmalu končana, tiste, ki pa niso prišli v službo, so zamenjali slovenski uradniki. Za vse stavke, ki so Maistru povzročale precej težav, je bilo značilno, da so stavkajoči podpirali nemške zahteve po slovenskem ozemlju. Narodna vlada tokrat generala Maistra ni kritizirala.
} 
Sredi decembra 1918 so enote generala Maistra nadzirale največ ozemlja ob severni slovenski meji. Vse pogostejši posegi II. vojaškega okrožja pri narodni vladi $\mathrm{v}$ Ljubljani so v velikovškem okraju, ki je sprva spadal pod Štajersko obmejno poveljstvo, pripeljali do ustanovitve obmejnega poveljstva za Koroško. V pristojnosti Štajerskega obmejnega poveljstva, ki mu je general Rudolf Maister poveljeval od 1. novembra 1918 do 27. maja 1919, je bilo le še območje od Radgone do Dravograda (Vojni arhiv Ministarstva odbrane Republike Srbije). S preoblikovanjem sta bila iz bojev za severno mejo na Koroškem izločena ${ }^{25}$ general Maister in nadporočnik Franjo Malgaj, ki sta bila med najbojevitejšimi častniki.

Člani antantne študijske komisije, ki so se seznanjali s stanjem etnične podobe na Koroškem in Štajerskem, so prvič prišli na Štajersko 20. januarja 1919. General Maister je vedno poskušal na teh srečanjih dokazati, da so podatki o narodnostni sestavi prebivalstva, ki so jih komisiji dali Nemci, pristranski.

General Rudolf Maister je pred začetkom majske ofenzive 1919 postal 27. maja 1919 poveljnik Labotskega odreda. Enote, ki so sodelovale v ofenzivi, ki je potekala od 28. maja do 6. junija 1919, so bile razporejene v pet odredov: Jeseniški, Ljubeljski, Jezerski, Koroški in Labotski (Švajncer, 1990, str. 176). Poveljnik Labotskega odreda je bil do 18. junija 1919 (Vojni arhiv Ministarstva odbrane Republike Srbije).

Zmagovita ofenziva je vplivala na odločitev, da so generala Rudolfa Maistra imenovali 19. junija 1919 za poveljnika oziroma komandanta jugoslovanskih čet v Koroškem odredu. Na tej poveljniški dolžnosti je bil do 1. avgusta 1919, saj je 2. avgusta postal poveljnik Koroškega obmejnega poveljstva v coni A plebiscitnega ozemlja (Vojni arhiv Ministarstva odbrane Republike Srbije). Zavedal se je, da je treba Korošce v coni A tudi politično povezati, zato je 26. junija 1919 šestnajstim uglednim Slovencem s svojega območja dal pobudo, da so ustanovili narodni svet

\footnotetext{
${ }^{25}$ Narodna vlada za Slovenijo in njen poverjenik za narodno obrambo dr. Lovro Pogačnik se nista strinjala s pogajanji med generalom Rudolfom Maistrom in polkovnikom Rudolfom Passyjem. Zavzeli so stališče, da se je general Rudolf Maister pogajal o zadevah, za katere ni bil pristojen. To stališče je izhajalo iz ukaza poveljstva II. vojaškega okrožja v Ljubljani, ki je 22. novembra 1918 ukazalo novo ureditev poveljstev: pod štajersko obmejno poveljstvo SHS pod poveljstvom generala Rudolfa Maistra naj bi od takrat spadalo ozemlje od ogrsko-hrvatsko-štajerske meje do vključno črte Dob-Pliberk-kota Travnik; proti jugu sega štajersko obmejno poveljstvo SHS do južne meje okrajnih glavarstev Ptuj, Maribor in Slovenj Gradec. Območje Celja ni več spadalo pod štajersko obmejno poveljstvo, temveč je bilo neposredno podrejeno II. vojaškemu okrožju. Tako je general Maister izgubil pristojnost poveljevanja slovenskim enotam na območju vzhodne Koroške (25. seja narodne vlade SHS v Ljubljani z dne 28. novembra 1918 in 27. seja narodne vlade SHS v Ljubljani z dne 2. decembra 1918, v Sejni zapisniki Narodne vlade Slovencev, Hrvatov in Srbov v Ljubljani in Deželnih vlad za Slovenijo 1918-1921, 1. del: od 1. novembra 1918 do 26. februarja 1919, str. 1998, str. 142 in 155). General Maister se je vrnil na Koroško šele konec maja 1919 kot poveljnik Labotskega odreda v majski ofenzivi 1919 (28. maj-6. junij 1919). Po ukazu Narodne vlade so nadporočnika Franja Malgaja poslali z bojišča v Guštanj (Ravne na Koroškem) z nalogo, da osnuje nekakšno vojaško okrožje. Med avstrijsko protiofenzivo maja 1919, ki je bila odgovor na slovensko aprilsko ofenzivo, je pri Tolstem vrhu nameraval s četo ustaviti sovražnika, vendar naj bi se ponesrečil z ročno bombo. Posmrtno je bil odlikovan z redom Karađorđeve zvezde. Na mestu, kjer je padel, je bil leta 1924 odkrit spomenik; 1941 so ga nemške oblasti podrle, po vojni pa je bil obnovljen in leta 2010 prestavljen na ustreznejšo lokacijo. Malgajev pogum in značaj je popisal Prežihov Voranc v romanu Požganica.
} 
za Koroško, ki pa ni bil neposredni naslednik narodnega sveta iz časov prevrata novembra 1918 (Hartman, 1998, str. 80).

Poveljnik Koroškega obmejnega poveljstva je bil do 1. maja 1920, od takrat in do 18. septembra 1920 pa poveljnik policijskih enot za Koroško, ko so ga poklicali oziroma umaknili v Beograd in mu šele po izgubljenem koroškem plebiscitu dovolili vrnitev v Maribor. V Mariboru je bil poveljnik mesta Maribor od 18. septembra 1920 do 10. novembra 1921, nato pa so ga na Ministrstvu vojske in mornarice postavili 17. novembra 1921 za predsednika jugoslovanskega dela komisije za razmejitev s Kraljevino Italijo in v štab IV. armadnega območja (Vojni arhiv Ministarstva odbrane Republike Srbije).

Generala Rudolfa Maistra so za zasluge v vojnih letih 1917, 1918 in 1919, predvsem pa za uspešno poveljevanje $\mathrm{v}$ majski ofenzivi 1919, odlikovali z redom belega orla z meči III. stopnje (Služben vojni list, br. 17, 26. april 1920, str. 536). Regent Aleksander Karađorđević je imenoval z ukazom, številka 12229, z dne 24. julija 1920 v Zagrebu generala Rudolfa Maistra za častnega kraljevega adjutanta oziroma pribočnika (Službeni vojni list, br. 28., 8. julija 1920, str. 1148). Leta 1922 so se ga začele lotevati zdravstvene težave, ki jih niso mogli več pozdraviti. 2. oktobra 1923 je bil Rudolf Maister upokojen kot divizijski general vojske Kraljevine Srbov, Hrvatov in Slovencev. Tako je bil general Maister prvi general, Slovenec, v vojski skupne države južnoslovanskih narodov (Vojni arhiv Ministarstva odbrane Republike Srbije).

\subsection{Ocena dolgoročnih učinkov Maistrovega vojaškega delovanja}

Čeprav je bil general Rudolf Maister formalno usposobljen za poveljnika čete, se je v vrtincu zgodovinskih dogodkov, ki so vplivali na prihodnji razvoj Slovencev, izkazal kot izjemen taktik in strateg. V konkretnih razmerah je bila z vidika generala Maistra strategija opredelitev, kaj storiti za obrambo severne slovenske meje, taktika pa, kako to storiti s silami, ki jih je imel. Maistrova strateška odločitev je bila zelo preprosta in učinkovita, ki kaže tudi na njegov izjemen občutek za razmere, v katerih se je znašel, in njihovo dojemanje. Dobro je razumel, da so ugodne razmere nastopile s propadom Avstro-Ogrske in ustanovitvijo Države Slovencev, Hrvatov in Srbov. Brez izpolnitve prvega pogoja bi ostal črnovojniški major, ki bi ga po vojni hitro upokojili, brez drugega pogoja pa bi bil vsak njegov nastop v Mariboru samo osebna avantura z nejasnimi in nerealnimi cilji. Njegova izjemna strategija se je potrjevala z združevanjem vojaških in političnih odločitev, kar zmorejo le veliki vojskovodje. $\mathrm{Na}$ strateški ravni se je odločil osredotočiti glavnino svojih sil v Mariboru. Maribor je opredelil kot najpomembnejšo, glavno in zadnjo odporno točko; enote, ki jih je lahko pogrešal v mestu, pa je razporedil na najpomembnejše in izpostavljene točke ob razmejitveni črti. Tudi z vidika taktike so bili postopki zelo preprosti. Vojaška enota je prodrla v določen kraj in ga zasedla s pravico močnejšega.

Uspešnost generala Rudolfa Maistra je bila potrjena z njegovimi dosežki v prevratni dobi in v nadaljevanju bojev za severno mejo. Osvobodil je Maribor in Slovencem 
obranil velik del etničnega ozemlja. Brez njegovih odločnih posegov slovenska severna meja danes ne bi bila tam, kjer je.

\section{JAVNE OBLIKE SPOMINJANJA NA GENERALA MAISTRA NA MINISTRSTVU ZA OBRAMBO IN V SLOVENSKI VOJSKI}

Simonič utemeljuje, da je »mit zgodba, ki se je o določeni osebi, dogodku, prostoru ali pojavu oblikovala skozi čas in v sodobnosti deluje kot pomenski sklop ali identifikacijski kod« (2021, str. 282).

V nadaljevanju prek ikonografije spomenikov in drugih umetniških del, poimenovanja vojaških objektov in priznanj, spominskih sob, scenarijev slovesnosti in govorov ob praznikih in obletnicah, povezanih z generalom Maistrom, ter organiziranja kulturnih dogodkov, kot so razstave in likovne delavnice, proučujemo, kakšen je pomenski sklop oziroma kateri so elementi aktualne »veljavne« zgodbe o generalu Maistru v obrambnem sistemu. Vizualna ikonografija in ritualne prakse so namreč del dediščenja, sotvorec spomina na zgodovinske osebnosti, ki so deležne kolektivnega spoštovanja in spominjanja.

\subsection{Ikonografija in simbolika nekaterih pomembnih javno izpostavljenih} Maistrovih upodobitev na Ministrstvu za obrambo in v Slovenski vojski

Slovenski umetnostni zgodovinar Sergej Vrišer (1920-2004), ki je kot otrok opazoval generala Maistra na ulicah Maribora (1999, str. 3), navaja, da je bil general v času življenja večkrat upodobljen tudi zaradi svoje markantnosti. »Nasploh je bil Maister vse življenje privlačen ne le zaradi ognjevitosti svojega duha, marveč tudi kot postaven človek« (prav tam). Te upodobitve so bile podlaga tudi za marsikatero sodobno upodobitev generala Maistra, nastalo po njegovi smrti. V nadaljevanju opisujemo nekatere njegove najznačilnejše upodobitve, javno izpostavljene $\mathrm{v}$ prostorih in objektih obrambnega sistema.

\subsubsection{Spomenik generala Rudolfa Maistra pred Ministrstvom za obrambo}

Že ob vstopu v glavno stavbo Ministrstva za obrambo na Vojkovi 55 v Ljubljani daje monumentalni Maistrov konjeniški spomenik iz brona jasen znak, da spomin na generala Maistra zavzema pomembno mesto $\mathrm{v}$ simbolnem in vrednostnem prostoru obrambnega resorja. Spomenik, ki od leta 2000 stoji na častnem mestu pred Ministrstvom za obrambo, je delo akademskega kiparja Boštjana Putriha.

Komić Marn piše o tem, da je tip javnega spomenika, ki predstavlja jezdeca na konju, posvečen zlasti vladarjem in vojskovodjem. Pri tem gre za učinkovito sredstvo počastitve oziroma celo poveličevanja zaslužnega posameznika, pa tudi za načrtno poudarjanje državljanske oziroma narodne pripadnosti in samozavesti. General Rudolf Maister je edini Slovenec, ki je bil deležen takšne monumentalne 
upodobitve (vizualizacije) in njegova spomenika ${ }^{26} \mathrm{v}$ slovenski prestolnici sta danes edina primera na Slovenskem (2013, str. 95).

Ista avtorica tudi navaja, da so se v strokovni javnosti v obdobju razpisa in postavitve konjeniških Maistrovih spomenikov v Ljubljani ob izteku devetdesetih let prejšnjega stoletja pojavljala različna mnenja o primernosti konjeniškega spomenika, vendar je bilo med njimi tudi mnenje, da je »konjeniški spomenik kot tradicionalni atribut vojaka in simbol junaštva posebej primeren za podobo neustrašnega generala« (2013, str. 112).

Ciglenečki omenja »precej nenavadno držo jezdeca, ki si z desnico podpira brado, hkrati pa jo opira na pokrčeno levico.« Spomni tudi na svetleče zvezdice, s katerimi je posuto telo konja, s čimer je po njenem mnenju avtor želel opozoriti na vstop Slovenije v Evropsko unijo (2011, str. 173). Tudi Komić Marn spomenik opisuje kot upodobitev »generala, ki nosi vojaško uniformo, si z desnico zamišljeno podpira brado, v pokrčeni levici pa stiska bič« (2013, str. 111). Komelj Maistra v Putrihovi kiparski upodobitvi opisuje kot »mirujočega, četudi notranje napetega med pričakovanjem, medtem ko na konju z napeto izproženim poudarjenim vratnim lokom kot globoko zamišljen premišljevalec tuhta o svoji usodni odločitvi.« Omenja tudi razlage, da gre »za napetost pred dejanjem, če že ne za zatišje pred viharjem« ali pa tudi da gre za »nekonvencionalno povezavo vojaka in filozofa« (2018, str. 263).

Figura konja je gotovo eden izmed poglavitnih in najbolj značilnih elementov tega spomenika in mu daje tudi širšo prepoznavnost. Ob tem se lahko vprašamo, koliko je konj pravzaprav značilen za generala Maistra. V obdobju razpisa in postavitve konjeniških Maistrovih spomenikov v Ljubljani ob izteku devetdesetih let prejšnjega stoletja se je namreč - kot navaja Komelj - »ob vprašanju konjenika med nasprotniki konjeniške postavitve pojavilo tudi vprašanje, ali je general Maister sploh bil jezdec.« Komelj v nadaljevanju trdi, da »najbrž to samo po sebi niti ni bistveno, že glede na to, da je spomenik jezdeca v osnovi simbolen« (2018, str. 260). Dejstvo pa je, kot že prej omenjamo, da je Rudolf Maister - in kot navajajo Hartman, Glavan, Komić Marn in Komelj - od novembra 1896 do aprila 1897 v Ljubljani obiskoval jezdarsko šolo za pehotne častnike in jo tudi uspešno končal (1998, str. 17; 2018, str. 13; 2013, str. 112 in 2018, str. 260).

\subsubsection{Spomenik generala Rudolfa Maistra v Vojašnici generala Maistra v Mariboru}

Poleg spomenika pred Ministrstvom za obrambo stoji na simbolno zelo pomembnem mestu tudi Maistrov spomenik v Vojašnici generala Maistra v Mariboru, pred stavbo poveljstva 72. brigade Slovenske vojske.

\footnotetext{
${ }^{26}$ Maistru sta v slovenskem glavnem mestu posvečena kar dva konjeniška spomenika; drugi, delo akademskega kiparja Jakova Brdarja, stoji nasproti glavne železniške postaje.
} 
Gre za repliko Maistrovega doprsnega kipa, ki ga je še v času Maistrovega življenja, leta 1926, ustvaril slovenski kipar, slikar in ilustrator Nikolaj Pirnat ${ }^{27}$ (1903-1948), ki je z Maistrom prijateljeval (Komelj, 2018, str. 252). Ciglenečki pojasnjuje, da je »kipar prikazal prav vse generalove telesne značilnosti in tudi na uniformi ni umanjkal noben detajl. Generalov obraz oblikujejo odločne, krepke poteze« (2011, str. 164). Pomemben je podatek, da je, kot piše Komelj, kipar Maistrovo »glavo obrnil vstran, gotovo v smer, od koder preži zgodovinska nevarnost, in videti je, kot bi se v tako profiliranem kipu idealno zlili v eno tako bojevnikovo kot kiparjevo odločnost« (2018, str. 253).

Ciglenečki piše tudi o tem, da se je lokacija tega (izvornega) kipa od prve postavitve do zdaj že večkrat spremenila. Leta 1934 je dala mariborska občina mavčni kip odliti v bron, kip so postavili v avlo rotovža. Kip so nato še večkrat prestavili, kar je povezano s spreminjajočim se odnosom do Maistra in njegovih zaslug. Od osamosvojitve naprej ta kip ponovno neprekinjeno stoji na prvotnem mestu, v avli Mestne občine Maribor (2011, str. 163-164). ${ }^{28}$

\subsubsection{Slikarska upodobitev v avli Kadetnice}

Med slikarskimi upodobitvami generala Maistra v prostorih ministrstva in Slovenske vojske izpostavljamo Maistrov portret v mariborski Kadetnici ${ }^{29}$. Na enem izmed dveh platen ${ }^{30}$, ki visita $v$ niši nasproti glavnega vhoda $v$ avli Kadetnice in merita skoraj pet metrov v višino, je doprsni portret generala Rudolfa Maistra. Naslikal ga je akademski slikar Dušan Fišer.

Kot ga opisuje Ciglenečki, je Maistrov doprsni portret naslikan v ovalu v levi polovici platna, v spodnjem delu pa je avtor upodobil mimohod Maistrovih čet na trgu pred mariborskim gradom (prizor s fotografije iz leta 1919). »Za ovalom s portretom se vrstijo verzi iz Maistrovih rokopisov in še za njimi se po nebu, ki ga ožarja rdečina poslednjih sončnih žarkov, podijo oblaki. Ob spodnjem robu je nekaj odlomkov iz Maistrovega razglasa o razpustitvi mariborske mestne straže« (Ciglenečki, 2011, str. 174).

Kot še piše Ciglenečki, »se ob poglobljenem opazovanju Fišerjevih slik posamezne plasti podobe začnejo navidezno seliti v prostor gledalca.« Tako naj bi deloval tudi ta Maistrov portret. »Če se prepustimo sicer realistično zastavljeni podobi, se naenkrat

\footnotetext{
${ }^{27}$ Kot navaja Ciglenečki, je Rudolf Maister Nikolaja Pirnata podpiral pri študiju (2011, str. 163, 164), Komelj pa navaja, da sta prijateljevala (2018, str. 252).

${ }^{28}$ O tem piše tudi Komelj (2018, str. 253).

${ }^{29}$ Pograjc in drugi pišejo o tem, da je general Rudolf Maister dal velik pečat Kadetnici, saj je novembra 1918, po tem, ko je v Mariboru prevzel vojaško oblast, kot poveljnik štajerskega obmejnega poveljstva zaradi neurejenih razmer v takratni vojaški realki predlagal Narodnemu svetu v Ljubljani, naj z Dunaja pokliče podpolkovnika Davorina Žunkoviča in ga imenuje za poveljnika vojaške realke v Mariboru. To se je tudi uresničilo, novi poveljnik je prevzel šolo 22. novembra 1918, in razmere v Kadetnici so se temeljito uredile (2010, str. 28).

${ }^{30}$ Na drugem platnu je upodobljen baron in topniški podpolkovnik Jurij Vega.
} 
zavemo, da je Maistrov lik napolnil prostornino v prehodu med avlo in stopniščem, mi pa stojimo tik ob generalu« (2011, prav tam).

\section{POČASTITVE DRŽAVNEGA PRAZNIKA DNEVA RUDOLFA MAISTRA}

Poleg vizualnih predstavitev se spomin na generala Maistra na Ministrstvu za obrambo in v Slovenski vojski predstavlja tudi v ritualnih počastitvah. Slavec Gradišnik trdi, da so »politični prazniki s svojimi rituali vedno osredinjeni na vprašanja skupnosti« (2017, str. 10). Simonič pa rituale opredeljuje kot »standardizirano, ponavljajočo se (komunikacijsko) dejanje« (2009, str. 80).

\subsection{Slovesnosti v počastitev spomina na generala Rudolfa Maistra na Ministrstvu za obrambo}

Kot navaja vodja Službe za protokol Aleš Obreht, poteka osrednja počastitev spomina na generala Rudolfa Maistra na Ministrstvu za obrambo vsako leto ob državnem prazniku, dnevu Rudolfa Maistra, 23. novembra. Scenarij slovesnosti je natančno določen. Začne se s polaganjem vencev pred Maistrovim spomenikom pred Ministrstvom za obrambo. Ob spomeniku stoji častna straža. Na desni strani spomenika stojijo nosilci praporov, trobilni kvintet Orkestra Slovenske vojske pa stoji vzporedno s spomenikom. Nato minister za obrambo v spremstvu načelnika Generalštaba Slovenske vojske in generalnega direktorja Uprave Republike Slovenije za zaščito in reševanje položi venec pred spomenik. Pripadnik Garde Slovenske vojske nosi venec pred ministrom. Med polaganjem venca igra zasedba Orkestra Slovenske vojske žalno koračnico. Delegaciji Zveze društev General Maister in Mestne občine Ljubljana položita venec. Po polaganju vencev se poveljuje »častni pozdrav«, trobentač Orkestra Slovenske vojske pa zaigra skladbo Domovini. Polaganju vencev sledi slovesnost v protokolarnih prostorih Ministrstva za obrambo. Na slovesnosti igrajo himno Republike Slovenije, sledijo govori ministra za obrambo ter drugih predstavnikov in na koncu kulturna točka, v kateri navadno interpretirajo tudi katero izmed Maistrovih pesmi.

Vsako leto, 29. marca, ob obletnici rojstva generala Maistra, položijo venec pred spomenik generala Maistra pred Ministrstvom za obrambo predstavniki Zveze društev General Maister. Ob tem dnevu tudi eden izmed visokih predstavnikov slovenske države položi venec pred spomenik generala Rudolfa Maistra nasproti glavne železniške postaje v Ljubljani (intervju, 12. april 2021).

Ministri in ministrice za obrambo so do zdaj v svojih govorih na slovesnostih $\mathrm{v}$ okviru obrambnega sistema ter tudi kot govorniki na državnih proslavah ob dnevu Rudolfa Maistra poudarjali njegovo predanost domoljubju, vizionarstvo, izjemno sposobnost na področju vojaške strategije, bojevniški duh, pa tudi državniško vlogo ter ga izpostavili kot zgled slovenske vojaške tradicije. Poudarjali so, da je tradicija generala Maistra in njegovih borcev eden izmed temeljev, na katerih gradi Slovenska vojska. Omenjali so tudi njegovo ustvarjanje na področju kulture, predvsem pa so mu 
v govorih priznali zaslugo, da smo zaradi njegovih hrabrih dejanj ter motiviranih in ustrezno opremljenih borcev, ki jih je imel ob sebi, do današnjih dni v trajni posesti ohranili pomemben del Slovenije.

Kot pravi strokovni vodja Orkestra Slovenske vojske višji vojaški uslužbenec Aljoša Deferri, ima orkester v svojem repertoarju tudi Koračnico generala Maistra avtorjev Franca Esa in Karla Klime ter Koračnico Rudolfa Maistra avtorja Slavka Avsenika ml., ki ju igra ob različnih slovesnostih, povezanih s spominom na generala Maistra, in tudi ob drugih primernih priložnostih (intervju, 19. aprila 2021).

\subsection{Slovesnosti v okviru 72. brigade}

72. brigada Slovenske vojske je bila ustanovljena septembra 1992. Matična vojašnica brigade je od leta 1992 poimenovana po generalu Maistru. S svojim delovanjem in vključenostjo v civilno okolje je brigada vzpostavila dobre odnose z Mestno občino Maribor. Rezultat dolgoletnega dobrega sodelovanja je tudi visoko priznanje, ki ga je mesto namenilo enoti, saj od aprila 2001 72. brigadi pripada domicil v mestu Maribor.

Povezanost enote in mesta se kaže tudi v prekrivanju zaznamovanja spomina na dogodke 23. novembra 1918, ko je general Maister dokončno razorožil pripadnike nemške zelene garde in preprečil morebitno umestitev Maribora v teritorialni okvir Avstrije. 23. november, državni praznik, dan Rudolfa Maistra, Mestna občina Maribor praznuje tudi kot občinski spominski dan, v 72. brigadi pa so 23. november izbrali za dan enote. Tako jasno sporoča širši javnosti, da enota povezuje svojo tradicijo s pomembnim in ponosnim poglavjem slovenske vojaške zgodovine.

Ena izmed najodmevnejših prireditev, ki jih pripravlja brigada, so Maistrove likovne delavnice. Na njih pripadniki Slovenske vojske in priznani slovenski umetniki kot gostje ustvarjajo na različne teme, ki so povezane z generalom Rudolfom Maistrom. Ob dnevih odprtih vrat vojašnice si lahko obiskovalci ogledajo spominsko sobo vojašnice, v kateri je na ogled manjša razstava o generalu Rudolfu Maistru.

\section{VOJAŠKI MUZEJ SLOVENSKE VOJSKE, EDEN IZMED NOSILCEV OHRANJANJA SPOMINA NA GENERALA MAISTRA}

Slovenska vojska omogoča podrobnejše spoznavanje izjemnosti generala Rudolfa Maistra in bojev za severno mejo 1918-1919 prek delovanja Vojaškega muzeja Slovenske vojske. Muzej je pripravil v mariborski Kadetnici dve stalni razstavi, in sicer General in pesnik Rudolf Maister - Vojanov (1874-1934) in Slovenci v prvi svetovni vojni in bojih za severno mejo 1914-1919. Poleg teh razstav muzej seznanja civilno javnost, predvsem osnovnošolsko in srednješolsko mladino, o pomenu generala Maistra in obdobju bojev za severno mejo z občasnimi gostujočimi razstavami. Muzej je pripravil tudi razstavi o generalu Maistru za Zvezo društev General Maister in za Maistrovo hišo na Uncu ter sodeloval z Medobčinskim muzejem Kamnik 
pri postavitvi stalne razstave o generalu Rudolfu Maistru v obnovljeni Maistrovi rojstni hiši v Kamniku. Muzej se je tudi dejavno vključil v projekt priprave virtualne učne poti o generalu Rudolfu Maistru, ki ga vodi Medobčinski muzej Kamnik. Pri projektu sodelujejo vsi pomembnejši muzeji, arhivi, knjižnice in druge ustanove ter posamezniki, ki se srečujemo z dediščino Rudolfa Maistra.

Številne dejavnosti, ki jih opravlja muzej zaradi boljšega poznavanja generala Rudolfa Maistra in časa, v katerem je živel, prispevajo h krepitvi državljanske in domoljubne zavesti ter dediščenju spomina na generala Rudolfa Maistra in borce za severno mejo.

\section{RED IN MEDALJA GENERALA MAISTRA}

Strmčnik ocenjuje, da imajo »vsa odličja nekakšen moralni pomen« (Strmčnik, 2018, str. 80). Pravilnik o priznanjih Ministrstva za obrambo v svojem 90. členu razvršča red generala Maistra kot drugega (takoj za častnim vojnim znakom), medaljo generala Maistra pa kot šesto po vrstnem redu pomembnosti glede nošenja nadomestne oznake.

Ministrstvo podeljuje red in medaljo generala Maistra na podlagi 2. člena omenjenega pravilnika »za zasluge, razvoj in krepitev obrambe države in Slovenske vojske, za zasluge, hrabrost ter uspehe pri opravljanju vojaške službe v miru in v vojni.« V nadaljevanju pravilnika so natančneje opredeljeni njune stopnje in kriteriji podeljevanja. Red generala Maistra je oblikovan kot okrogla medalja z likom generala Maistra in napisom GENERAL MAISTER. Medaljo obkroža venec lipovih listov. Nad medaljo je majhen venec z obročkom za trak (7. člen). V 6. členu je določeno, da se lahko red generala Maistra podeli častnikom in višjim vojaškim uslužbencem. Medalja generala Maistra se lahko podeli pripadnikom Slovenske vojske in tudi javnim uslužbencem ministrstva (10. člen). Medalja je okrogle oblike, na njej je upodobljen general Maister, ob njem je napis GENERAL MAISTER (11. člen).

Sklep Spomin na generala Rudolfa Maistra v samostojni Republiki Sloveniji na novo vrednotimo. V nekem obdobju po drugi svetovni vojni je bil z vidika javnega priznavanja pomena svojih zaslug zapostavljen. Številne oblike kolektivnega spominjanja v širšem okolju v zadnjih desetletjih kažejo, da se interes za poznavanje življenja in dela moža, ki je z neustrašnostjo obranil Maribor in severovzhodno Slovenijo po koncu prve svetovne vojne slovenski narodni skupnosti, izrazito povečuje.

Celovitost in pestrost prikaza osebnosti generala Rudolfa Maistra znotraj obrambnega sistema RS skozi ikonografijo javno izpostavljenih upodobitev, ritualnih počastitev, razstav, javnih govorov ter dejavnosti, usmerjenih k ozaveščanju osnovnošolske in srednješolske mladine, dokazuje, da se ga dojema kot celovito zgodovinsko vojaško osebnost. To še posebej poudarjajo značilnosti njegove vizualne podobe, kot so odločna telesna drža, generalska uniforma in podoba jezdeca na konju. 
Ministrstvo za obrambo in Slovenska vojska namenjata ohranjanju spomina na generala Maistra precejšnjo pozornost, kar poleg številnih vsakoletnih počastitev potrjujejo poimenovanje vojašnice v Mariboru, spomenika pred Ministrstvom za obrambo v Ljubljani in pred stavbo poveljstva 72. brigade Slovenske vojske ter stalna razstava Vojaškega muzeja Slovenske vojske v mariborski Kadetnici. Pri tem gre za stvarno kolektivno spominjanje na tega slovenskega vojaškega strateškega vodja, saj se v različnih oblikah dediščenja spomina nanj odslikava objektivno poznavanje zgodovinskih dejstev in priznavanja Maistrovega delovanja s časovne distance.

Razsežnosti, za katere smo predpostavljali, da generala Rudolfa Maistra v vrednostnem sistemu slovenskega obrambnega sistema določajo za izjemnega, so se v javnih oblikah spominjanja znotraj obrambnega sistema pokazale za pomembne, še posebej je izrazit poudarek na njegovem vplivu na oblikovanje slovenske države in njeno ozemeljsko celovitost ter na njegovem statusu generala. $\mathrm{V}$ javnih predstavitvah generala Maistra se obrambna oziroma vojaška dejavnost potrjuje kot zelo pomembna za doseganje državotvornih interesov. Menimo, da je pogled na generala Maistra stvaren, njegov lik pa ni deležen mitiziranega občudovanja, temveč so njegovo vojaško in državotvorno delovanje, pa tudi življenjska pot ter kulturno-umetniško delovanje realno odslikani skozi javne oblike spominjanja nanj. Tradicija in način dediščenja spomina generala Maistra dokazujeta, da je general Rudolf Maister prikazan kot vzornik pripadniku Slovenske vojske.

Pomemben je namreč razmislek, kaj bi se zgodilo z Mariborom in Podravjem, morda tudi še z obsežnejšim delom slovenskega ozemlja, če ne bi bilo odločnega, premišljenega, pa tudi drznega generala Maistra, ki se je zavedal prelomnega trenutka - tak zgodovinski trenutek je bil tudi leta 1991 - in s pravimi domoljubi ohranil ta kos slovenske zemlje naši narodni skupnosti. Slovenija bi bila manjša in težje bi se uveljavljala v gospodarstvu, politiki, kulturi in mednarodnem okolju. Maribor in njegovo širše zaledje, ki bi bilo vključeno v drugo državo, bi gotovo doživljala germanizacijo, ki se je začela že v začetku 20. stoletja. Da se to ni zgodilo, je zasluga generala Maistra in njegovih borcev. Zanj bo obveljalo, da je bil junak in dober vojaški poveljnik, ki je v tako rekoč brezupnih razmerah vojaško ukrepal in pomagal ustvariti slovenskemu narodu dom ter državo. 
1. Bjelajac, M., 2004. Generali i admirali Kraljevine Jugoslavije 1918-1941. Beograd: Institut za noviju istoriju.

2. Ciglenečki, M., 2011. Upodobitve Rudolfa Maistra. Časopis za zgodovino in narodopisje, letnik 82, zvezek 3-4, str. 156-179.

3. Enciklopedija Slovenije, zvezek 7. Ljubljana: 1993.

4. Furlan, B., 2013. Rudolf Maister-strateški vodja. Sodobni vojaški izzivi. 15/4, str. 73-81.

5. Glavan, M., 2018. Rod in dom. N. Malečkar, ur. Rudolf Maister: sto let severne meje: življenje in delo Rudolfa Maistra Vojanova 1874-1934. Ljubljana: Mladinska knjiga, str. 7-74.

6. Gradnik, V.,1981. Primorski prostovoljci v boju za severno mejo. Koper: Lipa.

7. Grdina, I., 2018. Odločilna dan in noč v novembru 1918. N. Malečkar, ur. Rudolf Maister: sto let severne meje: življenje in delo Rudolfa Maistra Vojanova 1874-1934. Ljubljana: Mladinska knjiga, str. 75-87.

8. Guštin, D., 2006. Oborožene sile Države SHS. V J. Fischer, ur. Slovenska novejša zgodovina: od programa Zedinjena Slovenija do mednarodnega priznanja Republike Slovenije: 1848-1992. Ljubljana: Mladinska knjiga: Inštitut za novejšo zgodovino, str. 192-196.

9. Guštin, D., 2006. Spopadi za meje. V J. Fischer, ur. Slovenska novejša zgodovina: od programa Zedinjena Slovenija do mednarodnega priznanja Republike Slovenije: 1848-1992. Ljubljana: Mladinska knjiga: Inštitut za novejšo zgodovino, str. 196-198.

10. Guštin, D., 2011. Strateško-operativna (za)misel Rudolfa Maistra o uporabi oboroženih sil v času gradnje nacionalne države 1918-1919. Časopis za zgodovino in narodopisje. 2-3, str. 18-36.

11. Hartman, B., 1998. Rudolf Maister, general in pesnik. Ljubljana: DZS.

12. Intervju z vodjo Službe za protokol na Ministrstvu za obrambo Alešem Obrehtom (12. aprila 2021).

13. Intervju s strokovnim vodjem Orkestra Slovenske vojske višjim vojaškim uslužbencem Aljošo Deferrijem (19. aprila 2021).

14. Koblar, F., Slovenska biografija. Maister, Rudolf. https://www.slovenska-biografija.si/ oseba/sbi340526/. 30. 4. 2021

15. Komelj, M., 2018. Pesniški general kot likovni spomenik. Malečkar, N., ur. Rudolf Maister: sto let severne meje: življenje in delo Rudolfa Maistra Vojanova 1874-1934. Ljubljana: Mladinska knjiga, str. 249-270.

16. Komić Marn, R., 2013. Možje na konjih. Vloga in recepcija konjeniškega spomenika na Slovenskem. Acta historiae artis Slovenica, letnik 18, št. 2., str. 75-94.

17. Kranjc, M. F., 2005. Slovenska vojaška inteligenca. Grosuplje: Grafis Trade.

18. Križnar, I., 1998. Jože Jelenc in Franc Potočnik, Maistrova borca za severno mejo. Loški razgledi. 45, 267-272.

19. Maister, R., 1979. Mariborski dogodki 1. novembra 1918 (iz rokopisa generala Maistra »Naš Maribor «). V J. Kuster in V. Lešnik, ur. Spominski zbornik ob 60-letnici bojev za severno slovensko mejo 1918-1919. Maribor: Zveza prostovoljcev - borcev za severno slovensko mejo 1918-1919, Klub koroških Slovencev in Sklad Prežihovega Voranca v Mariboru, str. 18-21.

20. Maister, R., 1979. Marburger Schutzwehr-Mariborska varnostna straža. V J. Kuster in V. Lešnik, ur. Spominski zbornik ob 60-letnici bojev za severno slovensko mejo 1918-1919. Maribor: Zveza prostovoljcev - borcev za severno slovensko mejo 1918-1919, Klub koroških Slovencev in Sklad Prežihovega Voranca v Mariboru, str. 39-52.

21. Maister, R., 1979. Prevzem mestne uprave v Mariboru, dne 2. januarja 1919. VJ. Kuster in V. Lešnik, ur. Spominski zbornik ob 60-letnici bojev za severno slovensko mejo 19181919. Maribor: Zveza prostovoljcev - borcev za severno slovensko mejo 1918-1919, Klub koroških Slovencev in Sklad Prežihovega Voranca v Mariboru, str. 63-65. 
22. Partljič, T., 2011. Rudolf Maister v knjigah. M. Toš, ur. Zbornik referatov ob 25-letnici Maistrovih prireditev in 50-letnici Turističnega društva Rudolf Maister Vojanov Zavrh. Lenart: Občina, str. 25-28.

23. Pavšič, J., 2019. Upodobitve generala Maistra v ilustriranih pripovedih za mladino. Monitor ISH, Revija za humanistične in družbene vede. XXX/1, str. 31-51.

24. Perovšek, J., 1998. Slovenska osamosvojitev v letu 1918. Ljubljana, Modrijan.

25. Perovšek, J., 2006. Slovenska samostojnost v Državi SHS. V J. Fischer, ur. Slovenska novejša zgodovina: od programa Zedinjena Slovenija do mednarodnega priznanja Republike Slovenije: 1848-1992. Ljubljana: Mladinska knjiga: Inštitut za novejšo zgodovino, str. 186-190.

26. Perovšek, J., 2018. Slovenski prevrat 1918: položaj Slovencev v Državi Slovencev, Hrvatov in Srbov. Ljubljana: Inštitut za novejšo zgodovino.

27. Pograjc, B., Kladnik, T., Hartman, B., Lazarini, F., Krajnc Horvat, I., Čepić, B., 2010. Kadetnica. Brodnik, A., ur., Ljubljana: Defensor.

28. Potočnik, D., 2008. Zgodovinske okoliščine delovanja generala Rudolfa Maistra na Štajerskem, Koroškem in v Prekmurju. Ljubljana: Koščak.

29. Pravilnik o priznanjih Ministrstva za obrambo (Uradni list RS, št. 41/07, 4/11, 86/21, 105/13, 37/15, 72/18 in 32/21).

30. Simonič, P., 2009. Kaj si bo narod mislil? Ritual slovenske državnosti. Ljubljana: Znanstvena založba Filozofske fakultete Univerze v Ljubljani.

31. Simonič, P., 2021. Maistrovo stoletje: od vojaka do mita. Fikfak, J., in Jezernik, B., ur. Dediščina prve svetovne vojne: interpretacije in reinterpretacije. Ljubljana: E-knjigeZnanstvena založba Filozofske fakultete Univerze v Ljubljani, str. 267-288.

32. Slavec Gradišnik, I., 2017. O koledarjih, praznikih in praznovanjih. Jezernik B., in Slavec Gradišnik I., ur. Države praznujejo: državni prazniki in skupnosti na območju bivše Jugoslavije. Ljubljana: Znanstvena založba Filozofske fakultete Univerze v Ljubljani, str. 9-23.

33. Strmčnik, M., 2018. Javne reprezentacije narodnih herojev Jugoslavije v Sloveniji, doktorska disertacija. Ljubljana: Filozofska fakulteta.

34. Službeni vojni list, br. 48, 3. december 1919.

35. Službeni vojni list, br. 17, 26. april 1920.

36. Službeni vojni list, br. 28, 8. julija 1920.

37. Šimac, M., in Torkar, B. (ur.), 2018. Stražarji Karavank: Lojze Ude in boji za severno mejo. Kranj: Društvo general Rudolf Maister.

38. Šnuderl, M., 1968. Osvobojene meje: kronika Maribora in slovenske severne meje v letih 1918/19. Maribor: Založba obzorja Maribor.

39. Švajncer, J. J., 2014. General Rudolf Maister: zamolčano. Logatec: Vojni muzej Logatec.

40. Švajncer, J. J., 1992. Vojna in vojaška zgodovina Slovencev. Ljubljana: Prě̌ernova družba.

41. Švajncer, J. J., 1990. Slovenska vojska 1918-1919. Ljubljana: Prě̌ernova družba.

42. Taškar, J., 2005. Največjo veljavo ima kulturni praznik. Delo. 4. junij, str. 2.

43. Ude, L., 1977. Boj za sevrno mejo 1918-1919. Maribor: Založba Obzorja.

44. Vrišer, S., Vrišer. A., Radovanovič, S., 1999. Z iskro v očeh, Nekaj misli ob upodobitvah Rudolfa Maistra. Vrišer, S., ur. Podoba vojaka: general Rudolf Maister: fotografije in likovna dela. Maribor: Pokrajinski muzej Maribor, str. 3-13. 


\section{Arhivski viri}

Arhiv Republike Slovenije (ARS)

- ARS1: AS 61, Poverjeništvo/Oddelek za notranje zadeve NV SHS, DVS in PUS, t.e. 98, spis št. pov. 1307.

- ARS2: AS 1177, Zveza prostovoljcev borcev za severno slovensko mejo 1918-1919, t. e. 1, Boj slovenskih prostovoljcev za severno mejo l. 1918/19 (Zgodovinski opis), str. 3.

- ARS 3: ARS, AS 1177, Zveza prostovoljcev borcev za severno slovensko mejo 1918-1919, $t$. e. 1, Tovariši prostovoljci, borci za severno slovensko mejo 1918/1919, spoštovani gostje.

Pokrajinski arhiv Maribor (PAM)

- PAM 1: Prevratni dogodki za slovensko Štajersko, AŠ 5/224.

Vojni arhiv Ministarstva odbrane Republike Srbije (VA):

- VA, Fond Arhivska građa od 1847 do 1941, Vojska Kraljevine Jugoslavije od 1921 do 1941, Dosijea personalnih podataka oficira, podoficira i vojnih službenika Vojske Kraljevine Jugoslavije, dosije, Personalni karton Rudolf Maister. 